\title{
CANDIDA GLABRATA ESOPHAGITIS: NEW CASE REPORTS AND MANAGEMENT
}

\author{
Danielle Patrícia Cerqueira Macêdo ${ }^{1 *}$; Vanessa Karina Alves da Silva ${ }^{1}$; Aline Mary de Almeida Farias ${ }^{1}$; \\ Luciana Resende Bandeira de Melo ${ }^{1}$; Ana Botler Wilheim² ${ }^{2}$ Rejane Pereira Neves ${ }^{1}$
}

\author{
${ }^{1}$ Departamento de Micologia, Centro de Ciências Biológicas, Universidade Federal de Pernambuco, Recife, PE, Brasil; ${ }^{2}$ Setor de \\ Endoscopia Digestiva do Laboratório Geral do Hospital Universitário Oswaldo Cruz, Recife, PE, Brasil
}

Submitted: November 29, 2007; Returned to authors for corrections: March 09, 2008; Approved: May 04, 2008.

\begin{abstract}
Candida esophagitis (CE) is a common opportunistic infection in the immunocompromised host. C. glabrata is rarely cited as agent of $\mathrm{CE}$ and has been underestimated due to lack of proper identification. In this study, two cases of $C$. glabrata esophagitis in AIDS and chagasic patients are reported. Diagnosis of Candida species should be considered an important key for the ideal choice of antifungal therapy against this mycosis.
\end{abstract}

Key-words: Candida glabrata, esophagitis, AIDS, Chagas disease.

Candida esophagitis (CE) is a common opportunistic infection in the immunocompromised host. It is also believed to occur in debilitated patients who have received broad-spectrum antibiotics, steroids and immunosuppressants $(6,13,15)$.

Candida species are commensal organisms of the gastrointestinal tract. They colonize the esophagus in approximately $20 \%$ of healthy adults. C. albicans is the most virulent and common causative organism in CE. Other species, including C. tropicalis, C. krusei, and C. stellatoidea, have also been isolated (11). C. glabrata currently ranks second or third as the causative agent of superficial (oral, esophageal, vaginal, or urinary) or systemic Candida infections, which are often nosocomial (9). This species is rarely cited as agent of CE and has been underestimated due to lack of proper identification $(3,8,12)$.

Several endocrine disorders and medical conditions have been associated with $\mathrm{CE}$ with functional or mechanical obstruction of the esophagus accompanied with stasis and excessive growth of the yeast $(15,18)$.

This paper reports two cases of esophagitis caused by $C$. glabrata in immunocompromised patients, occurred in Oswaldo Cruz Hospital, Recife, Pernambuco, Brazil. The first case was a 46-year-old male, HIV-infected patient, who presented with disfagia and regurgitation accompanied with weight loss. He was not making use of anti-retroviral medications and exhibited serious immunological deficits. The second case was an 82year-old chagasic woman, who presented with dysphagia both to solids and liquids for the last two years with which occasional odynophagia, intermittent regurgitation and aspiration were associated. There was also a complaint of fever, chest pain and significant weight loss for the last one year. Both patients failing prophylactic antifungal treatment with fluconazole were examined for causative fungal agents.

$\mathrm{CE}$ had been diagnosed when characteristic Candida plaques were endoscopically (esophago-gastro-duodenoscopy) identified (Fig. 1A). The patients were submitted to an endoscopy of the upper digestive tract and the samples were collected from fragments of the esophageal mucosa with special instruments under sterilized conditions, and then processed at Medical Mycology Laboratory (Department of Mycology, Federal University of Pernambuco) for mycological confirmation of the etiological agent.

Clinical samples were stained with $20 \%$ potassium hydroxide $(\mathrm{KOH})$ to help to dissolve the debris, facilitating observation through direct microscopy of fungal elements. For culture, specimens were inoculated on Sabouraud Dextrose Agar (SDA) (Difco) with chloranphenicol $(50 \mathrm{mg} / \mathrm{L}$ ) contained in Petri dishes, incubated at $28^{\circ} \mathrm{C}$ for 72 hours and identification was conducted on the basis of their morphophysiological characteristics and biochemical tests such as auxanogram, zimogram, acid and

*Corresponding Author. Mailing address: R. Cardeal Arcoverde, 116/203, Graças, Recife, PE, Brasil. 52011-240 Fax: (+5581) 3223-5179. E-mail: danielle_xande@yahoo.com.br 
urease production according to Barnett et al. (1) and Hoog et $a l$. (4). The identification was confirmed by the VITEK 120 test (bioMerieux).

Direct microscopic examination of the samples with $\mathrm{KOH}$ mount showed hyaline, isolated and small blastoconidia (1 to $4 \mu \mathrm{m})$ (Figure 1B). Cultures produced glistening, smooth, creamcolored colonies which are relatively indistinguishable from those of other Candida species except for their cellular size, which is quite small. In fact, C. glabrata is the only Candida species that does not form pseudohyphae at temperatures above $37^{\circ} \mathrm{C}$ (3). Glucose, trehalose and ammonium sulfate were assimilated as carbon and nitrogen sources, and fermentation of these sugars occurred although there was no acid and urease production.

The biochemical reactions of C. glabrata are also quite distinct. In contrast to C. albicans, which ferments and/or assimilates a number of sugars, C. glabrata ferments and assimilates only glucose and trehalose. Indeed, among yeast species commonly isolated in a clinical mycology laboratory, C. glabrata is the only one which utilizes trehalose but not sucrose (5).

C. glabrata esophagitis grade II of Wilcox (15) was diagnosed in both cases by the presence of characteristic endoscopic findings such as whitish plaques and exudate (Fig. 1A) with mycological confirmation of the involved species.
Until recently, C. glabrata was considered a relatively nonpathogenic commensal fungal organism of human mucosal tissues. However, with the increased use of immunosuppressive agents, mucosal and systemic infections caused by this fungus have increased significantly, especially in the HIV-infected population. A major obstacle in these infections is their innate resistance to azole antimycotic therapy, which is very effective in treating infections caused by other Candida species $(6,16)$.

The digestive forms of Chagas disease are the dilatations that occur throughout the digestive tract jeopardizing the normal transit or even impeding it completely. Although the development of candidiasis in the obstructed esophagus is uncommon, some literature reviews and infrequent case reports suggest such an association. This report reinforces the facts that long-standing stasis in the esophagus can lead to secondary opportunistic infective esophagitis (2). According to Praveen et al. (10) in nearly $25 \%$ of the cases, underlying causes of esophageal stasis, e.g., megaesophagus, facilitate fungal colonization.

Based on Westwater et al. (14) C. glabrata strains colonize the alimentary tract and penetrate into the keratinized (cardiaantrum) gastric tissues, but in contrast to C. albicans, were unable to infect oroesophageal tissues. This 'stealth-like' behavior could explain the ability of $C$. glabrata to persist in infected tissues and survive as a commensal in the alimentary tract.
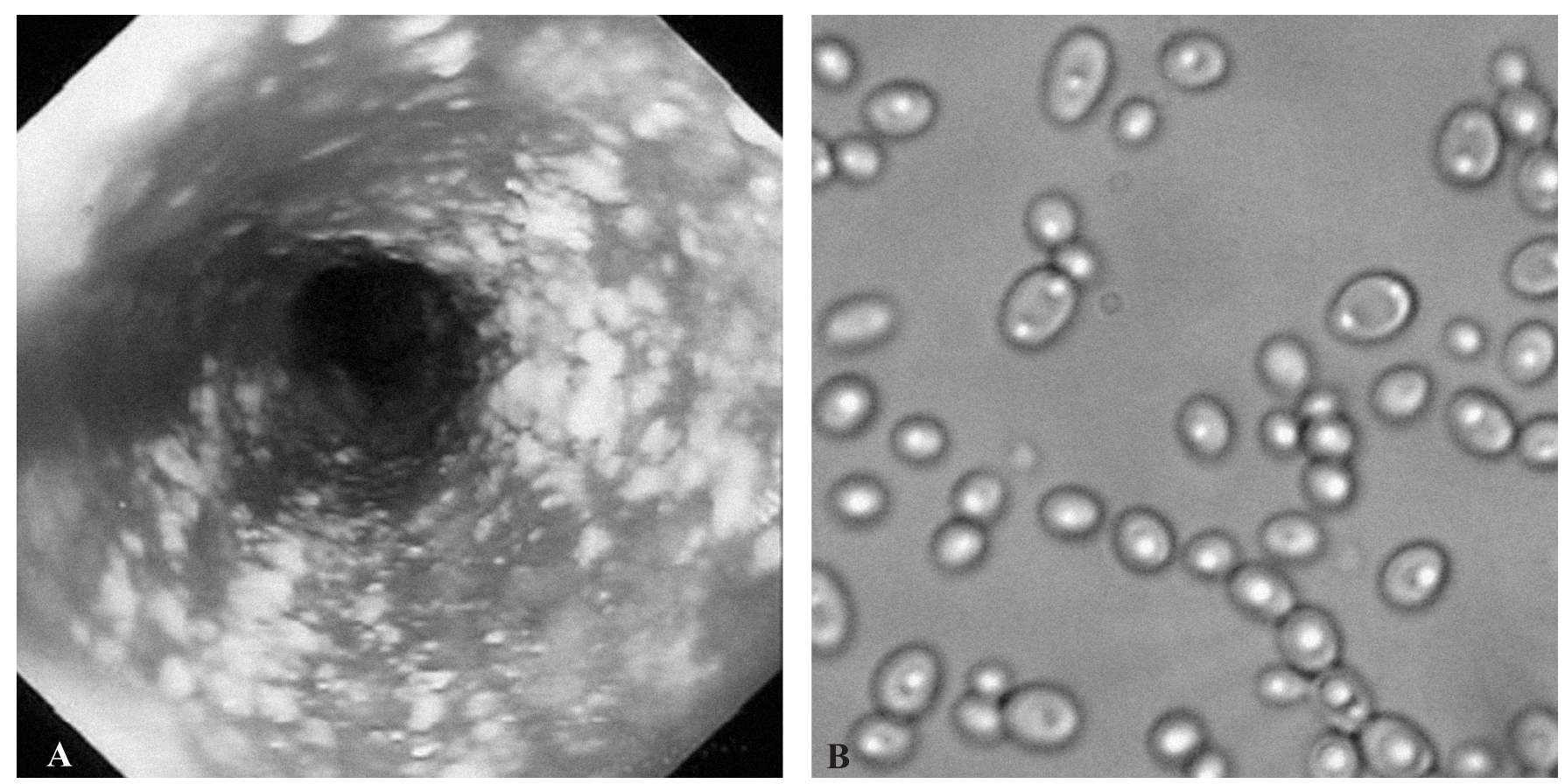

Figure 1. Endoscopic appearance of Candida glabrata esophagitis grade II of Wilcox (A) demonstrating white plaques and exudate characteristic of Candida esophagitis and direct examination of the lesion clarified with $20 \%$ potassium hydroxide solution showing numerous blastoconidia (B). 
In summary, both cases of CE by C. glabrata failed to develop fluconazole resistance. Thus, this emerging species may be underestimated due to lack of proper identification and may occur, in part, because of the impact of fluconazole therapy on the ecology of oral yeast species $(8,17)$.

The association of megaesophagus with Candida esophagitis is quite uncommon and an early diagnosis is mandated for adequate treatment of both these entities and for preventing the risk of metaplasia. Endoscopy with sampling for microbiological evaluation was however, the conclusive way to establish the diagnosis $(2,16)$.

These results suggest esophagitis by $C$. glabrata may be linked to immunocompromised hosts especially with chronic diseases, previously treated with antibiotics, steroids or omeprazole (7). Diagnosis of Candida species should be considered an important key for the ideal choice of antifungal therapy against this mycosis.

\section{RESUMO}

\section{Esofagite por Candida Glabrata: novos relatos de casos e conduta terapêutica}

Esofagite por Candida (CE) é uma infecção oportunista comum em hospedeiros imunocomprometidos. C. glabrata é raramente citada como agente de CE e tem sido subestimada devido à falta de uma identificação apropriada. Este estudo relata dois casos de esofagite por C. glabrata em pacientes com AIDS e doença de Chagas. O diagnóstico das espécies de Candida deveria ser considerado uma importante chave para a escolha da terapia antifúngica ideal contra esta micose.

Palavras-chave: Candida glabrata, esofagite, AIDS, doença de Chagas.

\section{REFERENCES}

1. Barnett, J.A.; Paine, R.W.; Yarrow, D. (2000). Yeasts: Characteristics and Identification. Cambridge, Cambridge University Press.

2. Crema, E.; Madureira, A.B.; Lima, V.G.F.; Castro, A.M.W.; Silva, A.A.; Junqueira, I.S. (2002). Microflora in chagasic megaesophagus Rev. Soc. Bras. Med. Trop., 35 (1), 39-42.
3. Fidel, P.L.J; Vazquez, J.A.; Sobel, J.D. (1999). Candida glabrata: review of epidemiology, pathogenesis, and clinical disease with comparison to C. albicans. Clin. Microbiol. Rev., 12 (1), 80-96.

4. Hoog, G.S.; Guarro, J.; Gene, J.; Figueras, M.J. (2000). Atlas of Clinical Fungi, 2 ed., Centraalbureau voor Schimmelcultures/UniversitatRovira i Virgili, Utrecht/Reus.

5. Kreger-Van Rij, N.J.W. (1984). The yeasts. A taxonomic study, 3rd ed. Elsevier Science Publishers, B.V., Amsterdam, The Netherlands.

6. Laine, L.; Boncini, M. (1994). Esophageal disease in Human Immunodeficiency Virus infection. Arch. Intern. Med., 154, 15771582 .

7. Martinez, A.C.; Tobal, F.G.; Ruiz-Irastorza, G.; López, A.G.; Navia, F.A.; Sangrador, C.O.; Arribas, M. (2000). Risk factors for esophageal candidiasis. Eur. J. Clin. Microbiol. Infect. Dis., 19, 96-100.

8. Martinez, M.; López-Ribot, J.L.; Kirkpatrick, W.R.; Coco, B.J.; Bachmann, S.P.; Patterson, T.F. (2002). Replacement of Candida albicans with $C$. dubliniensis in Human Immunodeficiency Virusinfected patients with oropharyngeal candidiasis treated with fluconazole. J. Clin. Microbiol., 40 (9), 3135-3139.

9. Neves, R.P.; Cavalcanti, M.A.Q.; Chaves, G.M.; Magalhães, O.M.C. (2002). Yeasts isolated from clinical samples of AIDS patients. Braz. J. Microbiol., 33 (4), 363-364.

10. Praveen, K.; Suyash, M.; Ashish, V.; Sanjay, B.S. (2007). Candida esophagitis in achalasia cardia: Case report and review of literature. Saudi J. Gastroenterol., 13 (2), 88-90.

11. Simon, M.R.; Houser, W.L.; Smith, K.A.; Long, P.M. (1997). Esophageal candidiasis as a complication of inhaled corticosteroids. Ann. Allergy Asthma Immunol., 79, 333-338.

12. Tran, H.A.M.; Vincent, J.M.; Slavin, M.A.; Grigg, A. (2003). Esophageal perforation secondary to angio-invasive Candida glabrata following hemopoietic stem cell transplantation. Clin. Microbiol. Infect., 9 (2), 1215-1218.

13. Weerasuriya, N.; Snape, J. (2006). A study of candida esophagitis in elderly patients attending a district general hospital in the UK. Diseases of the Esophagus, 19, 189-192.

14. Westwater, C.; Schofield, D.A.; Nicholas, P.J.; Paulling, E.; Balish, E. (2007). Candida glabrata and Candida albicans; dissimilar tissue tropism and infectivity in a gnotobiotic model of mucosal candidiasis. FEMS Immunol. Med. Microbiol., 51 (1), 134-139.

15. Wilcox, C.M.; Karowe, M.W. (1994). Esophageal infections: etiology, diagnosis and management. Gastroenterology, 2, 188-206.

16. Wilcox, C.M.; Straub, R.F.; Alexander, L.N.; Clark, W.S. (1996). Etiology of esophageal disease in Human Immunodeficiency Virusinfected patients who fail antifungal therapy. Inc. Am J Med., 101, 599-604.

17. Yakoob, J.; Jafri, W.; Abid, S.; Jafri, N. et al. (2003). Candida esophagitis: risk factors in non-HIV population in Pakistan. World J. Gastroenterol., 9, 2328-2331.

18. Yee, J.; Wall, S.D. (1994). Infectious esophagitis. Radiol. Clin. North Am., 32, 1135-1145. 